\title{
Northern Sotho Language
}

National Cancer Institute

\section{Source}

National Cancer Institute. Northern Sotho Language. NCI Thesaurus. Code C154061.

A Niger-Congo Bantu language spoken primarily in South Africa. 